\title{
Effect of High Dose Vitamin C on Folliculogenesis of Female Adult Wistar Rats (Rattus norvegicus)
}

\author{
L. Yenny Armayanti ${ }^{1}$, A. Aristo Parut ${ }^{2}$ \\ ${ }^{1,2}$ Institute of Health Science Bali, Jl. Tukad Balian no 180, Denpasar, Indonesia
}

\begin{abstract}
Vitamin $C$ is a Natural antioxidants that generally have beneficial health effect and marketed as a dietary suplement, partly because of its "antioxidant" properties. If the intakes of vitamin $C$ are very high, ascorbic acid remains in its oxidized form as dehydroascorbic acid and an ascorbate free radical, which may cause damage of macromolecules and cells. The aims of this study were to investigate the effect of administration of high dose vitamin C on folliculogenesis of female adult Wistar Rats (Rattus norvegicus). A total of twenty eight female Wistar rats were randomly divided into 4 group of 7 rats each. Group 1 as control was given distilled water 2 ml/week, group 2,3,4 as treatment groups were given Vitamin C 5,25 mg/week (subfisiologis), 8 mg/week (fisiologis), 17,5 mg/week (suprafisiologis) respectively. The number of secondary follicle and follicle de Graaf was count by Hematoxyclin Eosin Staining. The result showed a decrease of the number of secondary follicle and follicle de Graaf in group 4.Group 4 had lower number of of secondary follicle and follicle de Graaf compared with all treatment groups. There was no significant different betwen the number of follicle in group 1 with group 2 and $3(p>0,05)$, but there were a significant different in group 1 with group $4(p<0,05)$. The result of this study conclude that high dose vitamin C could decrease number of follicle in rat's ovarium.
\end{abstract}

Keyword: Vitamin C, Secondary Follicle, Follicle de Graaf

\section{Introduction}

Vitamin $\mathrm{C}$ is naturally occuring water soluble organic compound, obtained exogeneously by various dietary sources owing to the mutation of gene encoding for Lgulonolactone oxidase enzyme required for its synthesis [1]. Vitamin $\mathrm{C}$ is called an antioxidant because, by donating its electrons, it prevent other compound from being oxidized [1]. It can be a good free radical scavenger due to its chemical properties [2,3]. On the past few decades, practice of vitamin $\mathrm{C}$ injection is rapidly increase in Indonesia, especially in the center of the city. This phenomenon was caused by the increase of people interest on aesthetic function of antioxidant like vitamin C. Not only for injection, topical and peroral use of vitamin $\mathrm{C}$, can be found easily in the store as a health supplement and beauty or whitening agent.

Consuming vitamin $\mathrm{C}$ is not as simple as we know. Many people, especially women, undergo a non-prescription vitamin $\mathrm{C}$ injection from a general practicioner. They do not know the right and safe dose to achieve optimal results without give some adverse health effects. Most of them assumming the higher dose will give a better results.

Vitamin $\mathrm{C}$ has many benefit for our body because of its antioxidant properties. Lightening, and increase the production of collagen are some of the Vitamin $\mathrm{C}$ benefits. Vitamin $\mathrm{C}$ can help the skin looks younger and disguise scars. Our body needs $40-60 \mathrm{mg} /$ day of vitamin $\mathrm{c}$ to maintain our health and increase to $300-500 \%$ if we had infection, tuberculosis, neoplasm, post operative, trauma, hipertiroid, pregnancy and lactation [4]. In fact, injection of vitamin $\mathrm{C}$ for aesthetic purpose usually use 1 ampule of vitamin $\mathrm{C}$ /week that contain $1000-1800 \mathrm{mg}$ of vitamin $\mathrm{C}$.

Consumption of high dose of Vitamin $\mathrm{C}$, can leads change of antioksidant activity of vitamin $\mathrm{C}$ into prooksidant activity[5]. Its prooksidant activity can promote cell death, nuclear fragmentation, broke double strand DNA, stress oksidatif and contribute to free radical production [6].

High amount of prooxidant can induce stress oxidative which lead to macromolecule oxidation, gene mutation, aging and cell death. Stress oxidative play an important rule on release of sitokrom c, ATP depletion, and another apoptosis protein which provoke caspase activity and apoptosis [7].

Stress oxidative affect many organ on our body, like reproductive organ. The exposure of reactive oxygen species (ROS) accosiated with decline of fertility, blastocyt development, decrease on ovarian function and steroidogeneis [8,9] These affect woman's fertility condition. Fertility condition can be assesed by calculate the number follicle in the ovarium.

\section{Material and Methods}

\subsection{Animal}

This study used 28 female adult Wistar rats with 250-300 gram birth weight as sample. All rats were maintained under controlled condition: $25 \pm 2^{\circ} \mathrm{C}$ temperature, $50 \pm 15 \%$ relative humidity and normal photoperiod (12-hours light-dark cycle). Standar rats pellet and tap water were provide ad libithum for all rats.

\subsection{Experimental Protocol}

The female Wistar rats, after 7 days of adaptation were divided into 4 groups with 7 rats in each group. Control group (group 1) were given distilled water $2 \mathrm{ml} /$ week and group 1, 2, 3 were given Vitamin $\mathrm{C}$ with a dose of 5,25 $\mathrm{mg} /$ week (subfisiologis), $8 \mathrm{mg} /$ week (fisiologis), 17,5 $\mathrm{mg} /$ week (suprafisiologis) respectively by intramuscular injection. On the day 29, all rats were euthanasiaed and the 


\section{International Journal of Science and Research (IJSR) \\ ISSN (Online): 2319-7064}

Index Copernicus Value (2015): 78.96 | Impact Factor (2015): 6.391

ovarium tissue were taken to examine the number of secondary follicle and follicle de Graaf.

\subsection{Cytological Staining of Ovarian Tissue}

On the day 29 , all rats were euthanazied using high dose of ketamin $(132 \mathrm{mg} / \mathrm{kg}$ body weight) and the ovarium tissue (left and right) were taken to examine the number of secondary follicle and follicle de Graaf. The tissue was embedded in parafin wax and stained with Hematoxylin Ehrlich-Eosin. The number of secondary follicle and Graafian Follicle were counted per high power field (HPF, magnification $\mathrm{x} 400$ ).

\subsection{Data Analysis}

Mean difference of the number of follicle on each group, were analysed by One Way Anova and Post Hoc with 95\% Confident Interval.

\section{Result}

Anova analysis found no significant difference in the number of secondary follicle and follicle de Graaf among the four groups $(p<0,05)$. Post Hoc analysis found a significant mean difference of the number of the secondary follicle and follicle de Graaf between group 1 and 4 .

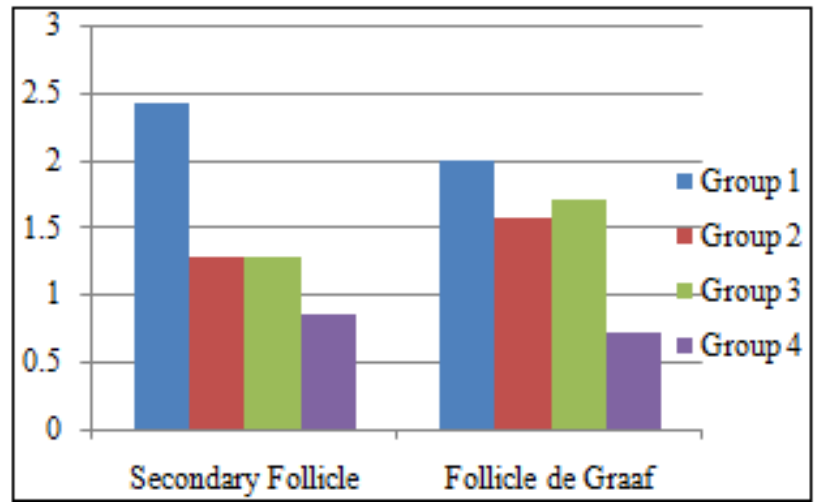

Figure 1: Number of secondary follicle and follicle de Graaf after 4 weeks of treatment.

Based on the figure 1. Secondary Follicle mostly found in control group. Mean of secondary follicle on the control group were $2,42 \pm 1,39$, subphysiologic group were $1,28 \pm 0,95$, physiologic group were $1,28 \pm 1,11$ and supraphysiologic group were $0,85 \pm 0,69$.

Number of follicle de Graaf mostly found in control group. Mean of follicle de Graaf on the control group were

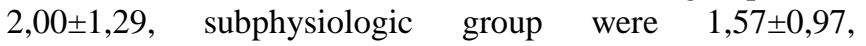
physiologic group were $1,71 \pm 1,11$ and supraphysiologic group were $0,71 \pm 0,75$.

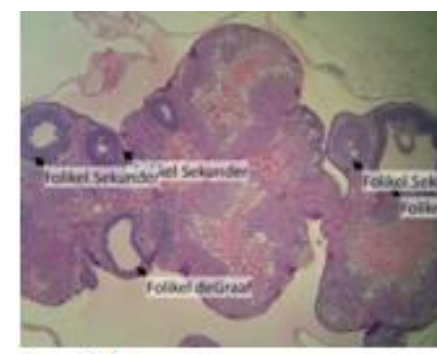

(a)

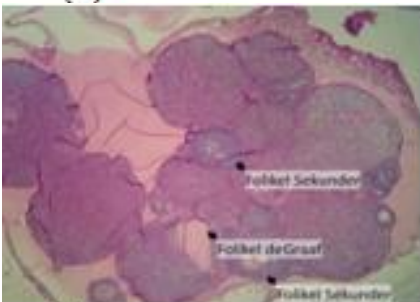

(c)

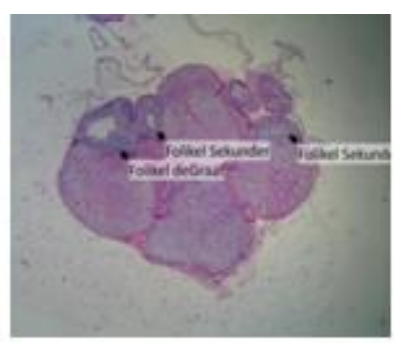

(b)

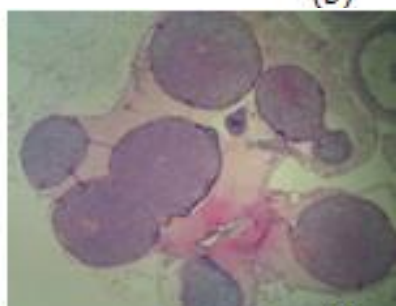

(d)
Figure 3: HE Staining of Rat's ovarian tissue sections from various treatment groups. (a) Control group (distilled water $2 \mathrm{ml} /$ week); (b) 5,25 mg/week; (c) $8 \mathrm{mg} /$ week; (d) 17,5 $\mathrm{mg} /$ week After an additional 4 weeks, all rats were euthanazied and ovarian tissues were removed, fixed in formalin, and embedded in parrafin wax and stained with Hematoxylin Ehrlich-Eosin and photographed at x400 magnification

\section{Discussion}

Antioxidant and free radical are term that are becoming most familiar to health conscious consumers. Health care providers recommend to consume rich antioxidant food such as fruit and vegetables as well as additional dietary antioxidant supplementation. These recommendations are based on a number of clinical studies that reveal the value of antioxidant in preventing disease and prolonging life. Various epidemiologic studies have confirmed that individuals with low level of antioxidant in their bodies are at greater risk for developing cardiovascular diseases and various types of cancer. This phenomenon is related to the generation excess of toxic free radicals.

Vitamin $\mathrm{C}$ is an essential nutrient for humans and a cofactor for collagen synthesis for maintenance of all oral hard and soft tissues. The biochemical and molecular roles can be accounted by its function as a reducing agent. This was observed by Padayatty et al [1]. In 2003 focusing on its property as an electron donor to prevent diseases in reduced intake attributing to its Antioxidant potential by forming ascorbyl radical; which is comparatively stable and less reactive in nature.

Vitamin $\mathrm{C}$ or ascorbic acid has antioxidant and prooxidant activity in the body. Consumption of Vitamin $\mathrm{C}$ is now increase among people who want to looks good and have a light colour of skin. Unfortunately, the use of vitamin C among women is often beyond the supervision of a doctor. Most of them assume that the higher dose of Vitamin $\mathrm{C}$ will show a better result.

In this study, we investigated the effect of hight dose of vitamin $\mathrm{C}$ on folliculogenesis. The administration exerted an effect on rats folliculogenesis, which was reduced the 


\section{International Journal of Science and Research (IJSR) \\ ISSN (Online): 2319-7064}

Index Copernicus Value (2015): 78.96 | Impact Factor (2015): 6.391

number of secondary follicle and follicle de Graaf compared than the other groups. The results of this study found no difference in the number of secondary follicles and follicles de Graaf between the control group, subfisiologis, physiological. But there were differences in the number of secondary and de Graaf follicles between the control and suprafisiological (High Dose) groups. This suggests that the consumption of Vitamin $\mathrm{C}$ in subfisiologically and physiologically doses in the unexposed to free radical agents does not affect the follicular folliculogenesis of the Rats. While the administration of Vitamin $\mathrm{C}$ in high doses leads to folliculogenesis disorders induced by the prooksidan activity of Vitamin C.

Antioxidants play a pivotal role as free radical and nonradical oxidant scavengers. Depending on the circumstances, a compound may exhibit pro or antioxidant activity. The protective effect of Vitamin $\mathrm{C}$ was further reported by Lee et al.[10] in 2003, it was also stated that at a higher dosage, it had induced oxidative damage to DNA promoting to pro-oxidant and mutagenic potential in humans. [11]

There is a continuing debate over the best dose schedule (the amount and frequency of intake) of Vitamin $\mathrm{C}$ for maintaining optimal oral health in humans. An average intake by healthy adults ranges from 90 to $100 \mathrm{mg}$ daily; while there is increased intake in pregnant and lactating women or individuals under stress. [12]

Herbert [13] in 1996, observed the pro-oxidant effects of antioxidant vitamins at a higher concentration, later supported by Azmi et al. [14] in 2003, linking to their anticarcinogenic property by generating reactive oxygen species.

Prooksidan activity of vitamin $\mathrm{C}$ appear when vitamin $\mathrm{C}$ neutralizes free radicals. in the process of neutralization of the free radical, the reducing agent becomes oxidized and needs to be regenerated to its reduced status to become a new antioxidant. Although antioxidants are known to have benefits in the prevention of disease and anti aging agent, some clinical studies prove that single antioxidants can change the antioxidant properties to be prooxidant under certain situations. In order to prevent the build up of the oxidized vitamin $\mathrm{C}$, the cells use their most important antioxidant partners, the Thione Complex ${ }^{\mathrm{TM}}$ to regenerate the vitamin $\mathrm{C}$ to its antioxidant property. The combination use of antioxidants showed a significant effect on the prevention of disease and cancer compared to a single antioxidant.

Various other studies have confirmed that consumption of a high dose of vitamin $\mathrm{C}$ may act as a prooxidant. Podmore, et.al., (1998) [15] gave $500 \mathrm{mg}$ of vitamin C to 30 volunteers for 6 weeks and found oxidative damage to blood lymphocytes. The parameter used to assess the anti- and prooxidant effects of vitamin $\mathrm{C}$ was the level of modified DNA bases detected in peripheral blood lymphocytes. Whereas the level of 8-oxoguanine was found to decrease upon supplementation relative to placebo indicating a genetic mutation. This biomarker returned to normal, six weeks after discontinuing of vitamin c supplementation. High doses of vitamin $\mathrm{C}$ cause decomposition of lipid hydroperoxide in various units of DNA, which causes mutations. So it can be concluded that the genotoxic effects of high dose vitamin $\mathrm{C}$ invitro.

On the follicologenesis, high doses of Vitamin C can induce apoptosis on ovarian follicles. An alternative mechanism suggested for the ascorbate-induced apoptosis is that induction of hypoxia-inducible factor $1-\alpha$ stabilizes p53 resulting in growth arrest or apoptosis [6]. Apoptosis in the ovarian follicle could dramatically decrease the number of follicles and inhibit ovulation and interfere with a woman's fertility.

High doses of vitamin $\mathrm{C}$ increase the formation of ROS (Reactive Oxygen Species). Oocyte ROS exposure associated with decreased fertilization and blastocyst development. [8]. Cyclical production of ROS contributes to decline in ovarian function and decreased steroidegenesis. Kadaman et al 2001. Decreased steroidogenesis inhibits the follicologenesis and decrease the chance of achieve pregnancy.

\section{Conclusion}

The administration of high dose vitamin $\mathrm{C}$ decrease folliculogenesis, through it's prooxidant activity and promote oxidative stress.

\section{References}

[1] Padayatty, S.J., et al., Vitamin C as an antioxidant: Evaluation of its role in disease prevention. 2003. J Am Coll Nutr 22: p. 18-35

[2] Buettner GR, Moseley PL: EPR spin trapping of free radicals produced by bleomycin and ascorbate. 1993. Free Radic Res Commun 19:S89-S93.

[3] Bielski BH, Richter HW, Chan PC: Some properties of the ascorbate free radical. 1975. Ann N Y Acad Sci 258:231-237

[4] Kamiensky M, Keogh J. 2006. Vitamin and Minerals.In: Pharmacology Demystified.Mc.GrawHill Companies Inc. USA

[5] Ivone, M.C.M.R., et.al. The Pro-oxidant chemistry of the natural antioxidant vitamin $\mathrm{C}$, Vitamin $\mathrm{E}$, carotenoid and flavonoid. 2002. Environmental Toxicology and Pharmacology 11:p. 321-333

[6] Sakagami, H., et.al.. Apoptosis-inducing activity of vitamin C and vitamin K. Cell. 2000 Mol.Biol. 46:129.

[7] Linda, Y, L., Ning, O., Qing-bin, L. Antioksidan induces DNA damage, cell death and mutagenicity ini normal human lung and skin normal celss. 2012. Scientific report: 3169

[8] Takahashi, T., et.al. Impact of oxidative stress in aged mouse oocytes on calcium oscillations at fertilization. 2003. Mol Reprod Dev 66: p.143-152.

[9] Kodaman PH, Behrman HR. Endocrine-regulated and protein kinase $\mathrm{C}$-dependent generation of superoxide by rat preovulatory follicles. 2001. Endocrinology 142: p.687-693.

[10]Lee KW, Lee HJ, Surh YJ, Lee CY. Vitamin C and cancer chemoprevention: Reappraisal. 2003. Am J Clin Nutr. 78: p. 1074-8

\section{Volume 6 Issue 7, July 2017 www.ijsr.net}




\section{International Journal of Science and Research (IJSR) \\ ISSN (Online): 2319-7064}

Index Copernicus Value (2015): 78.96 | Impact Factor (2015): 6.391

[11] Apsel N, Elisa R, Krishna MB. Vitamin C (ascorbic acid) does not exhibit mutagenic activity in vivo. 2011. Open Cell Dev Biol J.3: p. 6-9

[12] Schleicher RL, Carroll MD, Ford ES, Lacher DA. Serum vitamin $\mathrm{C}$ and the prevalence of vitamin $\mathrm{C}$ deficiency in the United States: 2003-2004 National Health and Nutrition Examination Survey (NHANES). 2009. Am J Clin Nutr 90: p. 1252-63

[13] Herbert V. Prooxidant effects of antioxidant vitamins. Introduction. 1996. J Nutr 126: p.1197S-200

[14] Azmi AS, Sarkar FH, Hadi SM. Pro-oxidant activity of dietary chemopreventive agents: An under-appreciated anti-cancer property. 2013. F1000Res. 2:135

[15] Podmore, I.D., et.al. Vitamin C exhibits pro-oxidant properties. 1998. Nature 9;392(6676):559

Volume 6 Issue 7, July 2017 www.ijsr.net 